\title{
PARADOX OF THE META-PRINCIPLES FOR SUSTAINABLE CITIES IN THE MORPHOLOGY AND CONFIGURATION OF THE CITY OF LISBON, PORTUGAL IN THE 20TH CENTURY
}

\author{
MARIA CATARINA J. B. SANTOS \\ Faculty of Architecture, University of Lisbon, Portugal
}

\begin{abstract}
Over the past few decades, we have lived a world transformation. Not just due to the population growth and high consumption of energy, but also the fast economic growth and the technology revolution. The rapid change of the world also originates from a sustainable conscience. Sustainability has become a need and a target to control, in a healthy way, the rapid urban sprawl and the subsequent exacerbation of social, environmental, and economic problems. However, many of these definitions suggest a range of contradictions, implying the achievement of sustainability. The city often revitalized through its history and constant development. It is essential to understand the morphology and configuration of the city, correctly apply the principles of sustainable development, and create conversions and brownfield developments to new construction opportunities. This paper aims to adjust the use of sustainability as a terminology in the field of sustainable urban development and compare them to the actual morphology and composition of the cities and their development models.
\end{abstract}

Keywords: cities, climate change, model, adaptability, Lisbon.

\section{INTRODUCTION}

To create sustainable cities is essential first to understand they are growing and the implications behind that. Within the spectrum of global, national, and local approaches, "cities play a crucial role to globally advance sustainable development given their share of the global population, global GDP, resource use, $\mathrm{CO}_{2}$ emissions, and associated dynamics" [1].

Societies can shape cities' typology because their socioeconomic models generate needs, and the demand for their resolution by urbanists gives rise to urban models. From antiquity to the twentieth century, these urban models, through their morphology and typology, mirror the civilizations' history that gave rise to them. The city and its form are intrinsic elements of the history of man as a social being.

There is a global consciousness that the cities should develop with an urban sustainable occupation model that responds to a greater awareness of the use of natural resources and the preservation of the environment [2].

The conception of urban form starts essentially from the concept of the city. However, defining the city is a daunting task because of the variety of criteria one can take into account. Its static definition expresses it as a minimal cluster of human beings in a restricted area, "we can define a city as population groups that do not produce their livelihoods themselves" [3]. The definition is currently changing due to the need for sustainability with which cities are to be endowed.

The city characterization is essential to consider functional criteria that give rise to urban rhythm and socio-cultural content. Therefore, to define the city, specific criteria are needed, in which the functional criteria that originate the urban rhythm and the socio-cultural content stand out. We can then say that the city's origin does not depend solely on the environmental factor or the factors related to the physical environment. The city is born as a result of 
historical, economic, social, and architectural aspects. "The growth of cities has always been correlated throughout history with the development of the means of transport and storage of goods needed to supply ever-increasing population numbers whatever the season" [3]. Social and cultural transformations over the centuries have reflected in the morphology of everchanging cities. Cities can now be seen as substantial raw material deposits and deposits of other features, including water, energy, and so far [4].

Cities now need to be looking for a valuable opportunity to increase urban resilience and improve residents' quality of life [2]. Urban areas must be deliberately secured and improved. Urban regeneration should be overseen and financed, "between competing uses of limited resources, have to be solved as has historically been the case with cities. Today urban citizens have more opportunities than ever to be involved in decisions that affect their daily lives and environment" [4].

\section{META-PRINCIPLES FOR SUSTAINABLE CITIES}

In Europe, more than two-thirds of the population resides in urban areas. Consequently, the range of challenges posed by climate change, economic transformation, and demographic shifts in the region is formidable, with governments and city mayors facing increasing pressure to find sustainable solutions [5].

The rapid change of the world has originated a sustainable conscience. Sustainability has become a need and target to control, in a healthy way, the rapid urban sprawl and the subsequent exacerbation of social, environmental, and economic problems. However, the term sustainability has associated several definitions, which makes its applicability difficult. Indeed, sustainability alone is not a sufficient objective. The word itself does not tell us what we are attempting to sustain. What we are attempting to support is the first example of wellbeing, strength, and versatility that keep up this planet in a condition where life overall can prosper. Design for sustainability is, ultimately, design for human and planetary health [6].

Even if the term sustainability is a current terminology, since the 19th century, the term Urban sustainability was not an issue either on the 19th since it was a moment of expansion and energy discoveries. The term "sustainability" was first mentioned in the IUCN report in 1980, which suggested its concept of concern for the quantity and form of consumption of natural resources. Preserve the integrity and operation of the various systems.

In 1987, the World Commission on Environment and Development, chaired by Gro Harlem Brundtland, defines the concept of sustainable development in its final report entitled "Our Common Future" or "Brundtland Report". Since the 1990s, the paradigm of sustainable urban development has been recognized. Indeed, It has become widely used in the "thirdway" policy to legitimize its agenda.

Sustainable development has acted as an arbiter between economic growth and environmental security. It was a useful concept for the "third power" policy that successfully solved the issues of conflict of interest in a new era of post-policy. The growing reappraisal of the values of capitalism and the economic recession also served as an impetus for the search for alternative forms of socio-economic development of society.

Although there are disagreements about the terms of sustainability and sustainable development, and the different concepts and definitions, it can be said that the concept of sustainable development has become a vast "umbrella", because it accommodates so many definitions today. It has begun to be a banalize word, and many theorists consider the term quite utopian. Even though the term sustainability has a broader definition like Sustainable cities, urban sustainability, or eco-city, to all these terms a city is designed with consideration for social, economic, environmental impact, it is also known as the triple bottom line, and 
"resilient habitat for existing populations, without compromising the ability of future generations to experience the same" [2].

The biggest concern is the real way to build cities, resulting from the urban sprawl and the unsustainable way to create cities. These issues have propelled organizers, geographers, and governments to look for proper ecological, economic, and social issues through sustainable developments.

\subsection{Sustainable development in the city}

The social-economic grown, in each country, have become a big concern of this century. The GDP of each country is an essential pillar of sustainable urban development, which the main idea is improving the lifestyle without harming the environment.

Some practical examples of sustainability may come from the past. The adverse conditions, in terms of location and the communication systems, have forced the creation of survival ways. These models can never be applied in modern society, either on a different scale or on the needs made essential today.

According to Rudlin and Falk [7], the last genuinely sustainable urban areas, at least in Europe, would have been the small medieval towns, dependent only on their surroundings, and with an environmental impact that could be absorbed by that same region. However, while these settlements incorporate targets that are valid for urban areas, such as full-scale self-generation of energy, which rarely exceeds five hundred people, they make most of the solutions used out of step with the needs of large urban centers and their neighborhoods constituents.

\subsection{The issues of implementation}

To implement sustainability, in the construction sector, it is essential to first look at the issues associated with it, regarding the focus on planning, management, and assessment of the human settlements. There are two points of view to approach this issue.

On the one hand, sustainability-oriented urban development is frequently part of national strategy. The need to arrange, plan and evaluate reasonable urban growth is a reaction to the development of urban areas and the increment in their populaces. The impact and control of practical urban improvement is an unpredictable task. One methodology is to subdivide the "city" framework into littler units and include neighborhood partners in the advancement of these units, not just as individuals are influenced by this wonder, but additionally as comakers. This methodology leads, among different outcomes, to the dynamic commitment to supportable neighborhood advancement. These considerations were developed from Local Agenda 21 [8].

On the other point of view, a concentrated assessment of the arranging, the executives, and evaluation of the sustainability of individual structures have been occurring in recent years. This development has brought an improvement in the construction of sustainable buildings and create several certification systems [9].

To achieve sustainable cities was created a program that looks to practices and policies to support cities and government programs preparing them for urban development challenges in the future, and this program is called Sustainable Cities Initiative (SCI) [10].

The program has eight sustainable development modules core values that are aimed to optimize the tree values of sustainability, which are [11]:

1. Historic City Conservation and Regeneration

2. Energy Efficiency and Climate Change 
3. Brownfield Development

4. Municipal Finance

5. Solid Waste Management

6. Water and Wastewater

7. Urban Transport

8. Social Inclusion

It is crucial to accomplish better sustainable cities understanding the different scales that these integrate. A city is also composed of neighborhoods and this one by buildings.

\subsection{Sustainable neighborhoods}

The neighborhood areas represent a half-level examination and activity between the city (and its parts) and individual structures. In contrast to urban areas and individual structures, neighborhoods show no explicit references to institutional and administrative boundaries.

This representation confuses the definition and outlines of neighborhoods that can be produced using a spatial, social, authoritative, or contextual point of view. Spatial framework limits are acclimated to fit the attributes of explicit criteria (like energy supply, trade, mobility, identity/sense of community).

A variety of different people composed a neighborhood development, some of them in an informal way and others in a formal way with networks. Neighborhoods excite in a no static state. They are consistently in permanent improvement. It is tough to portray a practical comparison of different neighborhood types and evaluation results along these lines. From one side, the "function" of a neighborhood cannot be characterized, and on the other side, there are neighborhoods with a variety of functions (residential, mixed-use, and so far) [11]. Suitable frameworks for arranging, overseeing, or educating the manageability of neighborhoods or their development must react to these characteristics.

In the last years, sustainability had not just focus on the city and neighborhoods but also on building efficiency [6]. Since these are the significant percent of the city mass, to respond to the need to address complex issues related to groups of buildings and neighborhoods, several certification systems and building sustainability assessments were developed.

The expanding affirmation and understanding that the way to supportability goes through the more extensive setting of the urban environment condition led to the ongoing improvement of a few global sustainability assessment systems on the neighborhood level. These can be separated into two principal classifications, the first incorporates existing and established third-party assessment and certification systems for buildings (such as LEED, BREEAM, GBC, Living building) [9]. The subsequent classification incorporates the frameworks implanted into neighborhood-scale plans and manageability activities expected to be utilized planning and decision-making support tools for the most part.

\subsection{Sustainable development in Portugal: Lisbon}

In Portugal, the history of sustainable development is a result of elaborating on the National Sustainable Development Strategy and its Implementation Plan. These reports and policies cannot deny external influences. Indeed it was that influence that has to dictate the environmental policy in Portugal, and consequently, the sustainable development concern [12].

The first big instrument of government policies and community policies, was the approval of the first Environment Law in 1987, where it was introduced, formally, the concept of sustainable development. This environmental policy's significant aim was to optimize and 
guarantee the correct use of natural resources in terms of quantity and quality [12]. (Lei no. 11/87, of 7 April da Assembleia da República, 1987). This law was extremely innovative in the protection of the environment.

This law has established the obligation of an annual Government report to the Republic Assembly of the environmental concerns. This report became known as the State of the Environment and Planning until 1993, later renamed "Report of the State of Environment". With 33 years of existence (1987-2020), the State of Environment's national report marked the area of the environment considerably. Indeed it became the reference document on environmental matters, assessing and communicating the state of the environment in Portugal [13].

It is essential to understand this national context to analyze the city of Lisbon. The implementation of national policies and the increase of a national environmental concern had made Lisbon the winner of the 2020 European Green City. The experts had highlighted the following positive aspects regarding the environmental policies that are being followed by the city of Lisbon (European Green Capital Award 2020: Technical Assessment Synopsis Report):

- It was the first European capital to sign the new Covenant for Climate and Energy;

- Achieved a 50\% reduction in $\mathrm{CO}_{2}$ emissions between 2002 and 2014;

- Reduced energy consumption by $23 \%$ and water consumption by $17 \%$ between 2007 and 2013;

- A clear vision for sustainable urban mobility, with measures to restrict car use and prioritize public transport and modes of mobility;

- Implement a bicycle sharing system, including electric bicycles;

- It has one of the largest electric vehicle transport networks in the world and $39 \%$ of the municipal electric vehicle fleet;

- Reveal a strong commitment to sustainability, notably its green infrastructure network as a tool to combat the effects of climate change.

\section{THE MORPHOLOGY OF THE CITY OF LISBON IN THE FIRST HALF THE TWENTIETH CENTURY}

In this section, the idea is to understand the morphology and configuration of Lisbon's city in a holistic view. To better understand how sustainability was integrated in the city's development, it was analyzed, each urban operation in terms of national and regional policies, urban configuration, innovative features, and sustainable principles applied to the developments. This analysis is made per decade and neighborhood, starting in the early 1920s and ending in the late 1940s with the most significant urban intervention.

\subsection{The 1920s: The Arco do Cego neighborhood}

The 20th century begins with the First Republic in power. The creation of Decree No. 4137, of 24 April 1918, legislates the need for large-scale construction of economic houses for the most disadvantaged working-class living in unhealthy and infected places. The housing policy, which was in vogue in more developed Europe, was defended. Thus were born in Lisbon, the projects of Arco do Cego, Alcântara, Ajuda, and Braço de Prata [14]. The first of these projects to be started was Arco do Cego. In 1921, all projects were suspended except the Arco do Cego neighborhood.

The Arco do Cego neighborhood was born in the current parish of Areeiro, between Saldanha and Campo Pequeno. Organized in a rectangle and oriented along orthogonal axes, 
it has 45 rectangular blocks with the symmetrical distribution that, in the initial project, consisted of 72 square houses of two or three floors, corresponding to 524 houses and 65 terraced houses, a theater and a market. There were several types of housing, and some had ateliers. According to the rules at the time, for housing, a rear yard of a minimum width of $4 \mathrm{~m}$ and, if possible, a small front garden was mandatory [15].

It was also mandatory by the height construction rules that the streets were at least $10 \mathrm{~m}$ wide, with macadam or sidewalk pavements and sidewalks. The existence of a sewerage network that connected the public sewerage to domestic sewage was also mandatory. Lighting, municipal cleaning, fountains, laundries, and buildings for schools and daycare centers were other mandatory measures at the time of the creation of the neighborhood project. Due to various irregularities, lack of structuring of the project phases and various budget overruns, this dreamed-up neighborhood, begun in the 1920s for the working population, was only completed in the mid-1930s and with a target audience that could afford the expensive housing prices, the burgeoning bourgeoisie of senior and middle civil servants [14].

When analyzing Arco do Cego, in terms of what Sustainability would be like, it is important to highlight an evident concern for house demand from the worker class. The initial idea was to incorporate a social dimension into the scope of development. It is also important to emphasize the integration of interurban land-use planning based on the prevailing hygienist. Indeed the project had innovative concerns, like connections to transports, services, and the integration of education facilities, that would reflect the beginning of sustainable development.

\subsection{The 1930s: Encarnação neighborhood}

In May 1932, Salazar moved from finance minister to the highest office in the nation and ironically governed the country's destiny and finances. Housing policies and their architectural morphology follow the maxims of the Estado Novo, and the link between family and home were two of its pillars [16]. Houses are not rented, they are sold. The idea of gigantic blocks of numbered dwellings as hotel rooms is repudiated; we want independent houses, our own homes whose fire is warming family love and strengthening the bonds of moral life was an excerpt from the speech of Engineer Teotónio Pereira, at the opening of the Arco do Cego neighborhood, an example of the policies of the time. In 1934 the Bairro da Ajuda was inaugurated, with two hundred houses whose project had been suspended in the First Republic and resumed in the Estado Novo. In 1935 the Bairro do Arco do Cego was inaugurated, a project modified for 483 homes. In 1938, the Bairro da Encarnação was born, the first project started in the Estado Novo.

The Encarnação neighborhood is a housing district, delimited by the 2nd Circular, Berlin Avenue and Moscavide Road. It is a neighborhood product of the application of the Urbanistic theory of Garden City in Portugal. The neighborhood has a primary and two secondary malls that two arteries join, thus allowing an orderly circulation. The threebedroom apartment typologies had a more privileged situation concerning the central circulation axis, the two-bedroom apartment, and one-bedroom apartment typologies were more inside of the neighborhood. The distribution follows symmetry, at the top of the central mall was the Church with the primary school next to, and at the bottom of the same avenue, the fire station. A market surrounded by various commercial establishments linked the secondary malls at their tops [15]. 
The Encarnação neighborhood has a garden area with about $20 \%-25 \%$ of its total area, as it was the only distraction or area dedicated to family leisure, given its remoteness at the time of Lisbon's central city [16].

The Estado Novo regime was notable, in terms of sustainability policies, in the social aspect. It created laws that favored the constitution of independent and healthy homes, particularly for the disadvantaged social classes, and for some professional groups. Indeed it was reconciling the economic dimension and the conditioned social dimension. One other concern was the integration and interaction of nature in the development.

\subsection{The 1940s: Alvalade neighborhood}

In 1945 is built the district of Alvalade neighborhood considered at the time distant from the city center required the development of the entire road network that unified the city.

Designed by João Faria Costa, it was inspired by the Modern Movement, more specifically by French urbanism, reinterpreted by the social and political demands of the time. Bordered by Brazil Avenue, United States Avenue, and Airport Avenue, it is divided into eight parcels, each with public equipment. The distance from the center of the plot to the equipment would have to be adapted to daily use needs. The maximum distance between the center of the plot and the daily use equipment had to be a maximum of $500 \mathrm{~m}$, and this condition dictated the design and size of each plot [16].

There is a hierarchy of roads and construction of squares, squares, garden spaces, and car parks, which were inside the plots, providing more exceptional ventilation and sun exposure. The pedestrian and road traffic were entirely distinct; the points of convergence of the roads gave rise to squares and wide. The landscaped pedestrian paths that lined the roads led to the creation of blocks [17].

The 1940s created the main public instrument for the organization and management of city life, namely the Urbanization Plan under the influence of Duarte Pacheco, marking a new dynamic in urban planning. This instrument had a critical role in the design of sustainable cities. Indeed this neighborhood has not just environmental and salubrity concerns, but it is the beginning of the incorporation of energy efficiency due to the integration of solar exposure and ventilation systems. However, the migration to cities, boosted by World War II, aggravated the housing situation of Portuguese families. Then, the State invested in the direct promotion of housing through the construction of social neighborhoods, destined not only for the lower classes but also for the middle class.

\section{CONCLUSIONS}

This paper makes clear that many criteria are used in practice to identify sustainability development. In practice, the principles of sustainable cities have many dimensions into consideration. It would have not just the economic, social, and environmental concerns but also the different interactions in the different scales of the city.

It is important to take into account the dynamic nature of social house problems, as well as planning, management of the new and existing neighborhoods to accurately implement policies that would increase the connections between the different areas, urban mobility, and integration of green spaces.

In the case study of Lisbon, it is notable the national concern to improve the city in a more sustainable way. This affords reflected on the recent Lisbon's award, in which it is possible to understand the importance of good local and national strategies.

Regarding the study of each neighborhood, it is conclusive that in the 1920s was tenuous incorporation of a social dimension into the realm of reality. Despite this effort, considered 
positive, the measures could not foster housing construction for the most disadvantaged classes. Throughout the 1930 s this social concern had a better impact as a final solution. The Alvalade neighborhood was, from the three decades, the most sustainable development in a holistic view.

\section{REFERENCES}

[1] Wheeler, S. \& Beatley, T. (eds.), The Sustainable Urban Development Reader, 2nd ed., London, 2009.

[2] Cohen, S., Defining the sustainable city. The Sustainable City, Columbia University Press: New York, pp. 3-14, 2018. DOI: 10.7312/cohe18204.5.

[3] Ascher, F., Modernities, Discontinuities and Urbanities: What Issues for European Town? European 5 Charter, Paris, 1997.

[4] Bundesministerium für Bildung und Forschung (ed.), Die Zukunftsstadt: $\mathrm{CO}_{2}$-neutral, energie-/ressourceneffizient, klimaangepasst und sozial. Langfassung der Strategischen Forschungs- und Innovationsagenda (FINA), BMBF, Referat Nachhaltigkeit, Klima, Energie: Berlin, 2015.

[5] Cao, X., Dai, X. \& Liu, J., Building energy-consumption status worldwide and the state-of-the-art technologies for zero-energy buildings during the past decade. Energy and Buildings, 2016. https://doi.org/10.1016/j.enbuild.2016.06.089.

[6] Wahl, C., Designing for Regenerative Cultures, Triarchy Press: Axminster, UK, 2016.

[7] Rudlin, D. \& Falk, N., Sustainable Urban Neighbourhood, Routledge: London, 2009. https://doi.org/10.4324/9780080939544.

[8] Keating, M., Agenda for Change: A Plain Language Version of Agenda 21 and Other Rio Agreements, Geneva (Centre for Our Common Future), 1993.

[9] Ebert, T., Eßig, N. \& Hauser, G., Green Building Certification Systems, Institut für Internationale Architekturdokumentation: Munich, 2011.

[10] CEC, Mainstreaming Sustainable Development into EU Policies: 2009 Review of the European Union Strategy for Sustainable Development. Communication from the Commission to the European Parliament, the Council, the European Economic and Social Committee and Committee of the Regions: Brussels, 24 Jul. 2009.

[11] European Union, Making our cities attractive and sustainable: How the EU contributes to improving the urban environment. Directorate-General for the Environment, 2010. https://doi.org/10.2779/42720.

[12] Rodrigues, V.J., Desenvolvimento Sustentável: Uma introdução crítica, 1st ed., Princípia Editora: Parede, 2009.

[13] Marcelino, M., Acesso do Público às Informações sobre Ambiente: Relatório de Portugal sobre a experiência adquirida na aplicação da Diretiva 2003/4/CE, pp. 1112, 2010. http://apambiente.pt/_cms/view/page_doc.php?id=579.

[14] Vasconcelos, C.N.B., Evolução social e transformação do espaço doméstico no Bairro Social do Arco do Cego em Lisboa: um estudo de um quarteirão de habitações unifamiliares reabilitadas. Dissertação de Mestrado em Arquitetura, Instituto Superior Técnico, Lisboa, 2010.

[15] Choay, F., Alegoria do Património, Lisboa, Edições 70, 2008.

[16] França, J.-A., Lisboa: urbanismo e arquitetura, biblioteca breve, 1st ed., Instituto de cultura e língua portuguesa, 1980.

[17] Salgado, M. \& Lourenço, N., Atlas Urbanistico de Lisboa, Lisboa Argumentum, 2006. 